\title{
In-vitro Assessment of Carbendazim and Copper oxychloride cytotoxicity on HaCaT and HepG2 human cell lines
}

\author{
Diksha Sateesh Bakre ${ }^{1}$, Basappa Basawanneppa Kaliwal ${ }^{2 *}$ \\ ${ }^{1}$ Department of studies in Biotechnology and Microbiology, Karnatak University, Dharwad, 580003, India. \\ ${ }^{2}$ Department of studies in Biotechnology and Microbiology, Davangere University, Shivagangothri, Davangere, India.
}

\section{ARTICLE INFO}

Article history:

Received on: 20/12/2016

Accepted on: 28/02/2017

Available online: 19/06/2017

Key words:

Carbendazim; Copper

oxychloride; HaCaT; HepG2;

MTT; Cytotoxicity.

\begin{abstract}
The objective of present study was to evaluate the cytotoxic effect of two fungicides i.e. carbendazim and copper oxychloride on human cell lines HaCaT [keratinocyte] and HepG2 [hepatoma cell line]. The cytotoxic study was done by following the standard MTT [3-[4,5-dimethylthiazol-2-yl]-2,5-diphehyltetrazolium bromide] assay along with standard drug. The MTT assay results showed that these two fungicides showed concentration dependent cytotoxicity, upon incubation for 24 hours with concentration ranging $20-450 \mu \mathrm{g} / \mathrm{ml}$ and $\mathrm{IC}_{50}$ values were determined. The cell viability of $\mathrm{HaCaT}$ cells decreased from $100 \%$ to $35.86 \%$ with increase in carbendazim concentration 20-450 $\mu \mathrm{g} / \mathrm{ml}$. Whereas HepG2 cells were sensitive towards Carbendazim treatment with the decrease in viability up to $30.98 \%$ at $450 \mu \mathrm{g} / \mathrm{ml}$. Copper oxychloride was more lethal, causing total cell death of $\mathrm{HaCaT}$ cells at $350 \mu \mathrm{g} / \mathrm{ml}$, and $\mathrm{HepG} 2$ at $450 \mu \mathrm{g} / \mathrm{ml}$ and the present work correlate this toxicity caused by these two fungicides on human skin and liver. The study unveils the cytotoxic effects of these fungicides on the skin as well as on the liver indicating the long term exposure to these compounds may lead to deleterious effects. Further study is needed on to identify the mechanism and pathway involved in the cytotoxic activity of these fungicides on $\mathrm{HaCaT}$ and HepG2 cell lines.
\end{abstract}

\section{INTRODUCTION}

From the era of civilization, the man was continuously engaged to improve his quality of life to overcome the basic needs by controlling the natural crop destroyer such as insects, weeds, pests etc. [1]. Therefore pesticides have important place among the xenobiotic compounds used by humans in regular basis. The pesticides were further simplified into herbicides, insecticides and fungicides which are extensively used in control of various plant diseases [2]. Pesticides which have high shelf life leave residues on and in the living system for longer duration, becoming the reason for the toxic symptoms [3]. These toxic effects have non targeted cytotoxic effects on living organisms including humans [4]. In recent years the study on toxic effects of pesticides has been gaining attention of researchers [5].Fungicides are the types of pesticides, which are extensively used eradicate and control the fungal diseases in plants.These are applied directly on seeds to control fungal infection, Sprayed on plants and field crops. These fungicides are made up of different

\footnotetext{
* Corresponding Author

Email: b_kaliwal@yahoo.com
}

chemical components [6]. These include organic and inorganic constituents. Metal and non-metal substances like copper, zinc, sulphur etc. Carbendazim and Copper oxychloride are one of the major systemic fungicides used in India to control fungal diseases. Carbendazim is a by-product of benomyl and thiophonate, belongs to the benzimidazole group of fungicide and play vital role in humoral immunity down regulation [7]. On other side, usage of copper based systemic fungicides in control of disease has been from early years. The largest usage of these pesticides started since1885, in combination with other fungicides and alone. Copper oxychloride is a major copper based systemic fungicide used to control the fungal diseases which directly damage the protein synthesis and lead to cellular injuries [8, 9]. The accumulation of heavy metal based fungicide in the living system lead to many hazardous health complications. Considering the cytotoxic properties of the xenobiotic compounds, it is valid to mention that these compounds have deleterious effect on microflora and other living organisms. Dermal toxicity term has reflected the views of toxicologists on the skin poisoning caused by the absorption of pesticides by the semipermeable membrane of the skin [10]. 
The most commonly faced xenobiotic compound infection is skin allergy, dermatitis, skin irritation and uncommon disease like urticaria, erythemamultiforme, ashy dermatosis, occupational acne, porphyria cutanea tarda, hair and nail disorders, and skin cancer occurs in long term exposure. Apart from skin disorders the other major toxicity can be seen on the liver systems. Liver is an organ which represents the biotransformation of endogenous and exogenous xenobiotics and becomes one of the major target in humans. Hence in this study the HepG2 cell line was used derived from a hepatoma which possesses a liver-like enzyme pattern including the enzymes of biotransformation [11], hence HepG2 cell line is majorly used for a toxicological research exposure approach [12].

Each and every day human being exposed to various types of xenobiotic compound in and around at regular basis within the household or by means of agriculture. It has become necessary to reduce the animal experimental model to assess the toxicity of these xenobiotic compounds as an alternative to elucidate the lethality to humans. Therefore the multicentre evaluation of In-vitro cytotoxicity [MEIC] concept came into existence by Born and Ekwall, where they evaluated the relevance of cytotoxicity on human specialized cells and correlated to the in vivo lethality [13]. The other common means to get effected by these chemical compounds is through consumption of food and agriculture is a destination for chemicals [14].

Therefore the aim of the current study was to evaluate the cytotoxic effect of carbendazim and copper oxychloride on skin and liver in an In-vitro system using HaCaT keratinocyte and Hepatoma cell line HepG2, to associate the cytotoxic behaviour of both fungicides on in-vivo system, further the cell morphological study was done by microscopy, to elucidate the dose dependent effect of Carbendazim and Copper oxychloride on the growth and proliferation of skin and liver cell line.

\section{MATERIALS AND METHODS}

\subsection{Cell culture and chemicals}

Skin cells [HaCaT] and hepatoma cell line [HepG2] were obtained from NCCS Pune. All other chemicals used were of analytical grade.

\subsection{Cell medium}

DMEM- high glucose and W-PBS were obtained from Invitrogen, and other chemicals for MTT and neutral red assay were purchased from Himedia. Carbendazim and copper oxychloride were obtained from Nagarjuna Agrichem pvt.ltd, and Parekh chemicals Gujarat respectively. Cell viability, morphology changes were evaluated by MTT cell viability assay and invertmicroscope observations.

\subsection{Preparation of standard solution:}

Carbendazim and copper oxychloride were used were technical grade with $98 \%$ purity. Both fungicides were dissolved in DMSO with the concentration $1 \mathrm{mg} / \mathrm{ml}$ and standard solution was prepared. For further analysis the solution was diluted as per the requirement.

\subsection{Cell culture conditions and MTT cell viability assay: 2.4.1 Cell seeding}

Skin cells $[\mathrm{HaCaT}]$ and hepatoma cell line [HepG2] were cultured on DMEM high glucose media for 24 hours. The cell growth was observed and evaluated by inverted phase microscope, further the cell density was calculated by haemocytometer before seeding into 96 well plates with the cell density of $1 \times 10^{3}$ cells in each well.

\subsubsection{Assay controls}

For cell viability assay three controls were retained throughout the experiment. The medium without cells was considered as medium control. The negative control was maintained with the medium containing cells without the experimental drug and a positive control with a known drug Metformin $[5 \mu \mathrm{M}]$.

\subsubsection{Cell viability assay}

MTT assay was used to assess the cytotoxicity of Carbendazim and Copper oxychloride on HaCaT and HepG2 cells. On 24 hours of incubation the media was replaced with fresh medium containing different concentrations of Carbendazim and Copper oxychloride, i.e., 20, 50, 150, 250, 350 and $450 \mu \mathrm{g} / \mathrm{ml}$. then the plates were incubated at $37^{\circ} \mathrm{C}$ in $5 \% \mathrm{CO}_{2}$ incubator for 24 hours. After discarding the medium, MTT solution [10\% of the total volume] was added to cells plate and incubated for $4 \mathrm{~h}$ with PBS [5 mg/ml], for the solubilisation of resulting formazan. After solubilisation of formazan, DMSO [100 $\mu \mathrm{l}]$ was added to the plate and shaken gently for 10 minutes. The absorbance was measured at $570 \mathrm{~nm}$ against blank [15]. The effect of different concentration of both fungicides on HaCaT and HEPG2 cells was studied to evaluate the dose dependent effect. The influence of each concentration on both cell lines was compared between the treated and untreated cells. The experiment was carried in triplicates for each concentration.

\subsection{Cell viability and morphological study using inverted microscope}

The viability and morphological studies of treated and non-treated cells was carried out using inverted microscope [Biolink at 10X]. Each concentration of Carbendazim and Copper oxychloride treated cells were subjected for the morphological study after the treatment of 24hours. The untreated cells served as a control. The cell disruption, viability of cells and cell death was noted.

\subsection{Determination of Half maximal inhibitory concentration $\left[\mathrm{IC}_{50}\right]$ value}

The cytotoxicity of Carbendazim and Copper oxychloride on the HaCaT human skin cell line and HepG2 hepatoma cell line was expressed in terms of $\mathrm{IC}_{50}$ value, using 
linear regression equation i.e. $\mathrm{Y}=\mathrm{Mx}+\mathrm{C}$. Here, $\mathrm{Y}=50$, $\mathrm{x}$ define the test drug $\mathrm{IC}_{50}$ value, where $\mathrm{M}$ and $\mathrm{C}$ represent the viability. The absorbance of the medium was recorded by 96 -well plate ELISA reader (Biotek) at 570nm.

\subsection{Statistical analysis}

The influences of Carbendazim and Copper oxychloride on $\mathrm{HaCaT}$ and HepG2cell lines were expressed as the ratio of cell proliferation of treated and untreated cells Statistical analysis was conducted with SPSS 20.0 [IBM] software. Three independent experiments were performed for each experimental condition, and the data were conveyed as mean. One-way analysis of variance was performed on multiple comparisons among treatment and control groups. Differences with $\mathrm{P}<0.05$ were considered as statistically significant.

\section{RESULTS AND DISCUSSION}

\subsection{MTT cell viability assay}

The use of pesticides in the field of agriculture is an issue of concern due to its high risk for environmental contamination, which simultaneously affects the quality of the food, safety of consumers as well as the users like farmers who come directly in contact of these xenobiotic compounds in regular basis during handling and using of these fungicides are risk to human health system. Therefor it is essential to create the awareness in public while using synthetic chemical compounds. So it is necessary to study the cytotoxic effects of these fungicides on human skin and liver, therefore the present study was undertaken to study the effect of carbendazim and copper oxychloride on $\mathrm{HaCaT}$ and HepG2 cell lines by using the standard MTT cytotoxicity assay. MTT is a tetrazolium salt which is reduced to purple formazan crystals by succinate dehydrogenase [16].

Carbendazim has been reported for being associated in chromosomal aberrations [17]. It is also has been used in antimicrotubular drugs preparations, which interfere in the synthesis of DNA and assembly of microtubules and tubulin subunits during cell cycle or cellular development [18, 19]. Ample amount of research has been done in In-vitro to study the deleterious effect of Carbendazim on rat model as well as human reproductive system, where it showed the significant decrease in the epididymal sperm count and fertility [20, 21]. The fig. 1 shows the effect of carbendazim on HaCaT cells $[p<0.05]$ after 24 hours treatment. The earlier study reported the anti-proliferative activity of carbendazim in other mammalian cells $[22,23]$. On treatment with carbendazim at $20 \mu \mathrm{g} / \mathrm{ml}$, HaCaT showed $51.48 \%$ of cell death, which was increased with increase in concentration and reduced the viability upto $35.86 \%$ at $450 \mu \mathrm{g} / \mathrm{ml}$ [fig. 1]. The hepatoma cells [HepG2] were more sensitive towards the less concentrations of carbendazim showing cell death of $58.53 \%$ which was not much altered at higher doses and showed $30.98 \%$ viability at $450 \mu \mathrm{g} / \mathrm{ml}$ [fig. 3]. With these observations, the present study also showed that carbendazim significantly increased the apoptosis of both cells in a dose dependent manner. In the earlier study it was reported that, the Carbendazim oral toxicity is lower in higher animals than the invertebrates. This may lead to teratogenicity in invertebrates under certain conditions. Carbendazim has been reported for the mitosis disruption in fungi [24], for mammalian cells [22, 23] in in-vivo and In-vitro studies.

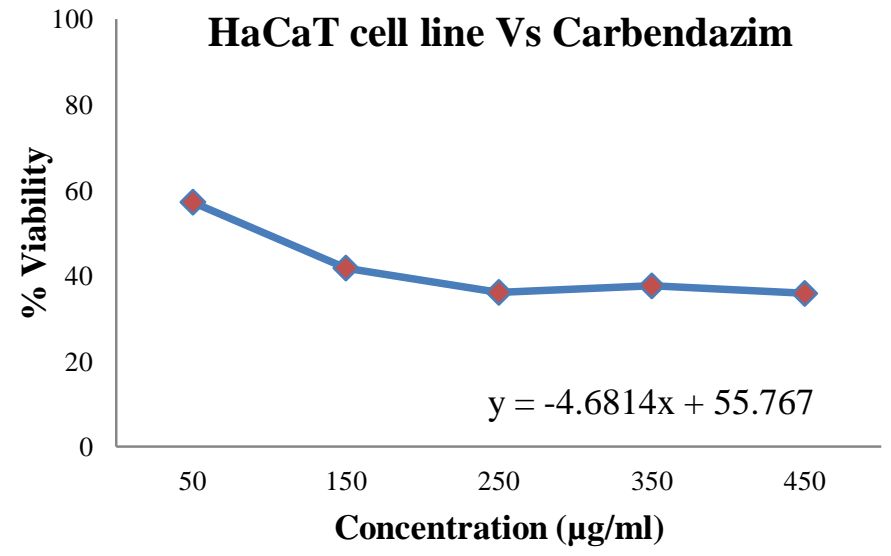

Fig. 1: Effect of Carbendazim on HaCaT cells at different concentrations. *p < 0.05 , compared with control group.

Copper oxychloride is another fungicide used extensively in agriculture to control fungal diseases. From the earlier study it was reported that, the chemically synthesized products specifically the products containing chlorine, may have the damaging effects on the genetic material of the eukaryotes as well on their reproductive system $[25,26]$. Copper oxychloride is another fungicide used widely in agriculture in control of many fungal diseases in agriculture. Several studies carried earlier have reported the metal ion toxicity in in vivo and in vitro systems. The studies undertaken by Wataha [27] observed the decrease in cell proliferation and the increase in no viable cells under higher copper concentrations, these observations were similar to the obtained results, and where on treatment with copper oxychloride at $20 \mu \mathrm{g} / \mathrm{ml}$ the viability of $\mathrm{HaCaT}$ cells was $51.48 \%$. The increase in copper oxychloride concentrations, the cell viability decreased to $3.37 \%$ at $250 \mu \mathrm{g} / \mathrm{ml}$ and no cell viability was observed at 350 and $450 \mu \mathrm{g} / \mathrm{ml}$ [fig. 2].

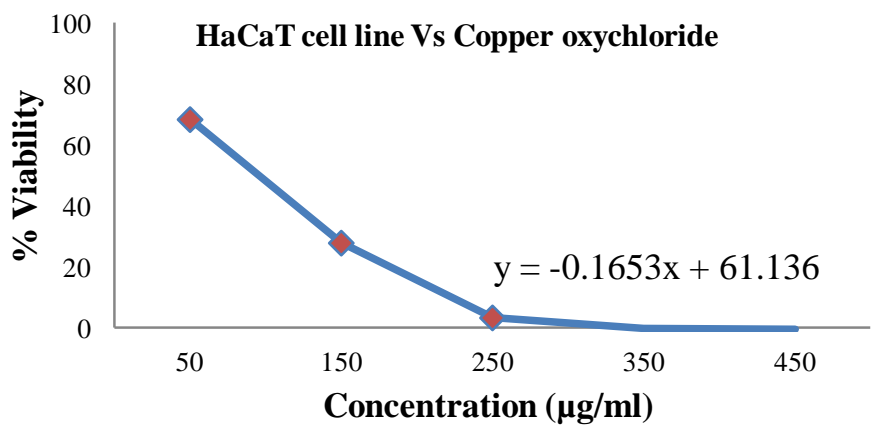

Fig. 2: Effect of Copper oxychloride on HaCaT cells at different concentrations. ${ }^{*} \mathrm{p}<0.05$, compared with control group.

The earlier studies also reported that the effect of copper changes with the difference in cell type, and the lethal effect vary 
[28-30]. This study supported to the observations where the copper oxychloride was less toxic to HepG2 cells at $20 \mu \mathrm{g} / \mathrm{ml}$ leaving $58.53 \%$ viable cells.

The HepG2 cells showed viability up to $5 \%$ at $350 \mu \mathrm{g} / \mathrm{ml}$ concentration of copper oxychloride. The total cell death was observed at $450 \mu \mathrm{g} / \mathrm{ml}$ [fig. 4]. Apart from antiproliferative effects, copper also induced the DNA damage in hepatic, renal and brain cells of LEC rats [31]. The copper also showed mutagenic and genotoxic effects on rats on feeding the water containing copper $[8 \mathrm{mg} / \mathrm{kg}]$ for six consecutive days. Therefore the toxic effects of copper are an issue of concern [32-42].

From the present study it appeared that the short term exposures lead to deleterious effects and may cause harm at long term exposure, although the in-vivo systems work differently and the toxic effect may reduce during metabolic processes, but this can be remunerated due to the accumulation of these xenobiotic compounds.

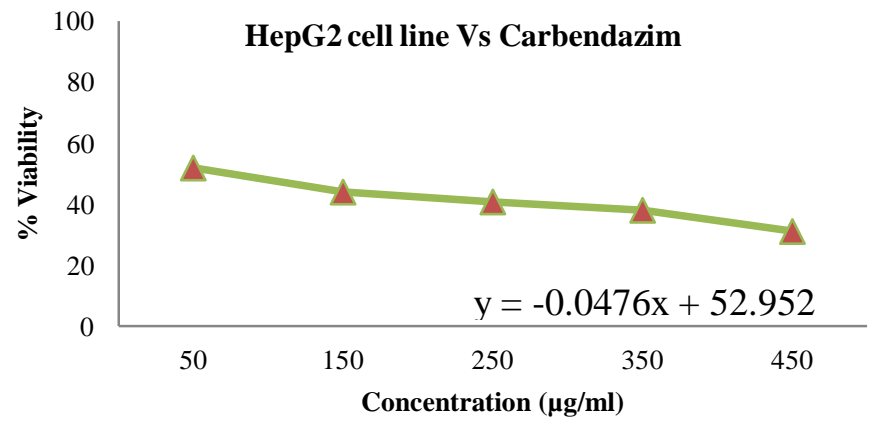

Fig. 3: Effect of Carbendazim on HepG2 cells at different concentrations. ${ }^{*} \mathrm{p}<$ 0.05 , compared with control group.

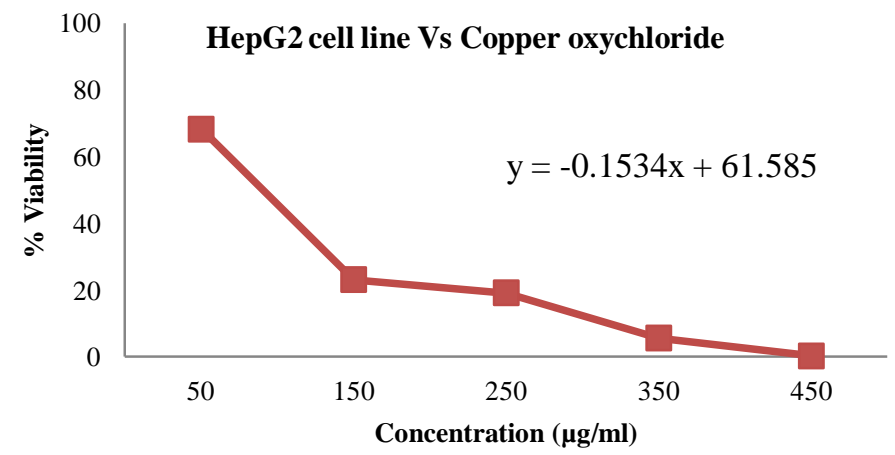

Fig. 4: Effect of Copper oxychloride on HepG2 cells at different concentrations. ${ }^{*} \mathrm{p}<0.05$, compared with control group.

The present study reveals that there was a noticeable significant difference in the activity of carbendazim and copper oxychloride on tested HaCaT and HepG2 human cell lines at different concentrations [20-450 $\mu \mathrm{g} / \mathrm{ml}$ ]. It was also observed that at the initial concentration $[20 \mu \mathrm{g} / \mathrm{ml}]$ the cell death was higher than $[50 \mu \mathrm{g} / \mathrm{ml}]$ concentration.

It may be due to the cells try to protect themselves from the exposure to toxic substances and the enzymatic activity may increase at lower concentrations and the cell death starts after certain concentrations. The study demonstrated the cytotoxic behaviour of carbendazim and copper oxychloride suggesting both the fungicides directly affect the viability of HaCaT and HepG2 cells at the $350 \mu \mathrm{g} / \mathrm{ml}$ concentration as shown in Table and Figures.

\subsection{Cell morphological study using inverted microscope:}

The cell morphological study was done using inverted microscope, where both cell lines morphological changes were observed on exposure to different concentrations of carbendazim and copper oxychloride ranging from $20-450 \mu \mathrm{g} / \mathrm{ml}$ for 24 hours. The untreated cells were taken as control. On treatment with carbendazim it was observed that the cells were dispersed throughout the culture medium and showed spherical morphology, whereas the control cells attached to the surface or to the plate and showed their elongated and flat morphologies fig. 5, 6 [A] and 7, 8 [A].
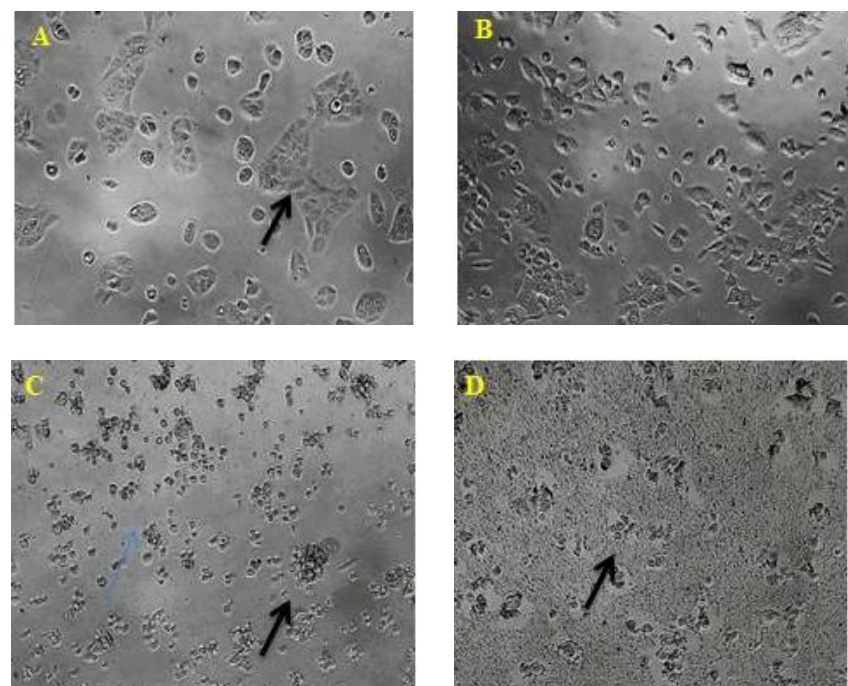

Fig. 5: Effect of carbendazim at different concentrations on Haca T cells. A] control cells B] cells at $50 \mu \mathrm{g} / \mathrm{ml} \mathrm{C]} \mathrm{cells} \mathrm{at} 250 \mu \mathrm{g} / \mathrm{ml} \mathrm{D]} \mathrm{cells} \mathrm{at} 450 \mu \mathrm{g} / \mathrm{ml}$.
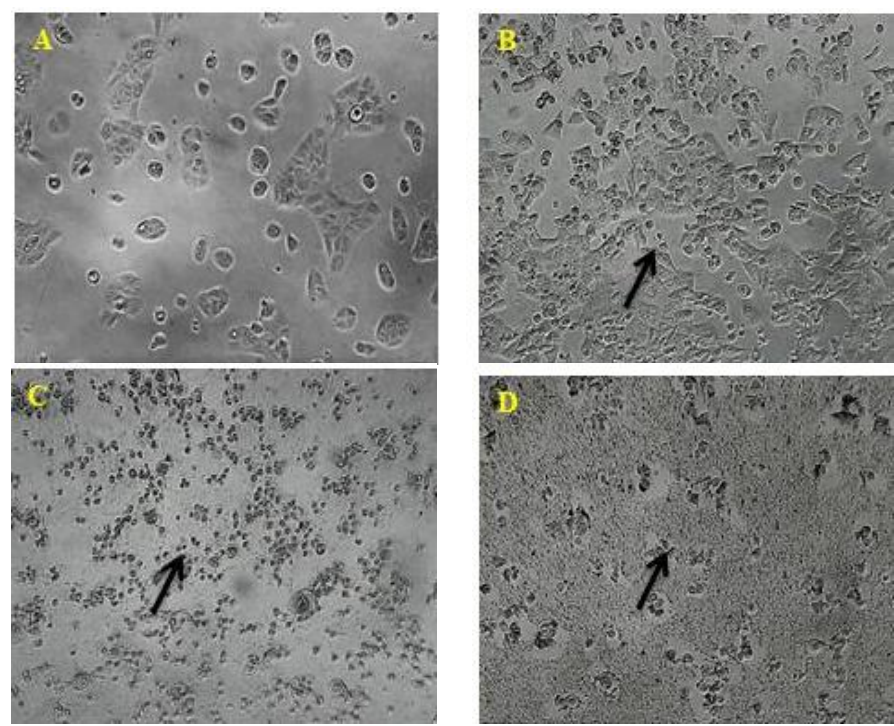

Fig. 6: Effect of copper oxychloride at different concentration on Haca T cells A] control cells B] cells at $50 \mathrm{mg} / \mathrm{ml} \mathrm{C}$ ] cells at $250 \mu \mathrm{g} / \mathrm{ml}$. 
The observations were similar to the earlier studies where the propiconazole fungicide exerted the similar effect on hepatoma cells on treatment with different concentration of this triazole fungicide [43].

Copper oxychloride also showed the similar behaviour on the cells causing cell death of both cell lines. The observations showed that the copper oxychloride was more harmful and caused complete cell death at lower concentrations in HaCaT cells. The cell morphological changes were observed where the treated cell showed the spherical morphology and the control cells remained intact to the surface and showed their elongated and flat morphologies Fig. $6[\mathrm{~B}],[\mathrm{C}]$ and $8[\mathrm{~B}],[\mathrm{C}]$. In both treatments the $\mathrm{HaCaT}$ and HepG2 cells on treatment with carbendazim $50-450 \mu \mathrm{g} / \mathrm{ml}$ concentration the cells became rounded and less adherent.
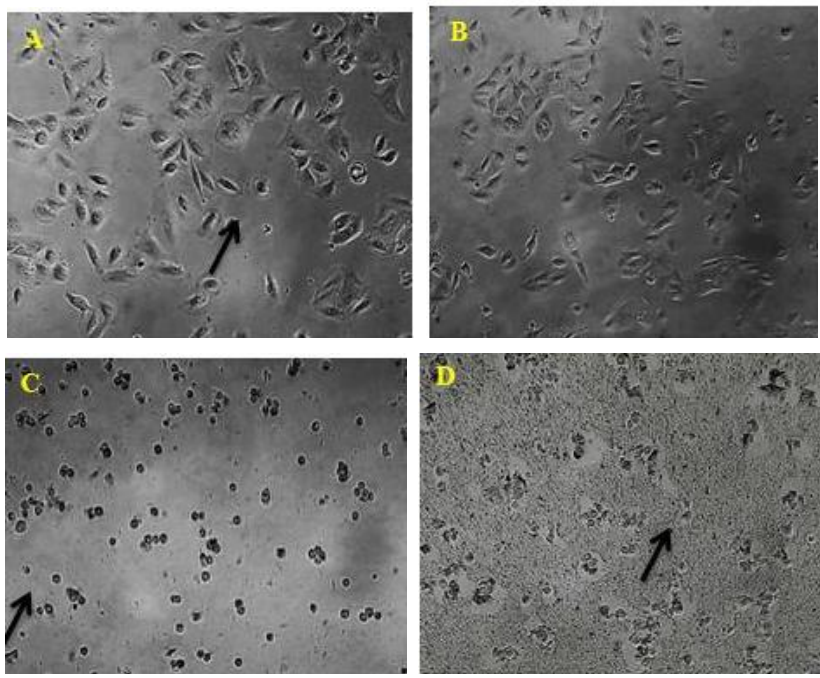

Fig. 7: Effect of carbendazim at different concentration on HepG2 cells. A control cells B] cells at $50 \mu \mathrm{g} / \mathrm{ml} \mathrm{C}$ ] cells at $250 \mu \mathrm{g} / \mathrm{ml} \mathrm{D}$ ] cells at $450 \mu \mathrm{g} / \mathrm{ml}$.
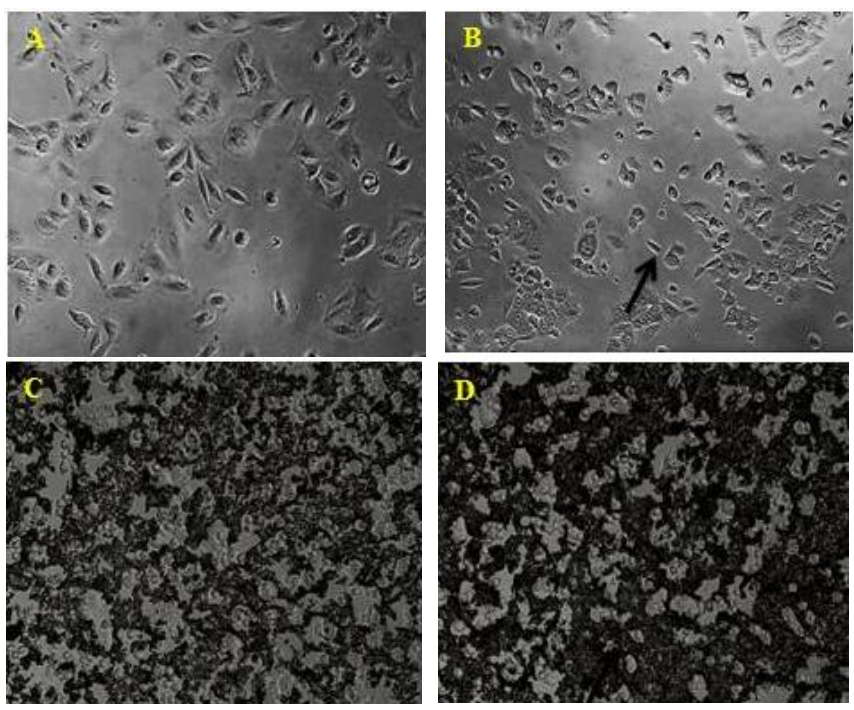

Fig. 8: Effect of copper oxychloride at different concentrations on HepG2 cells. A] control cells B] cells at $50 \mu \mathrm{g} / \mathrm{ml} \mathrm{C]} \mathrm{cells} \mathrm{at} 250 \mu \mathrm{g} / \mathrm{ml} \mathrm{D]} \mathrm{cells} \mathrm{at} 450$ $\mu \mathrm{g} / \mathrm{ml}$.

\subsection{Half maximal inhibitory concentration $\left[\mathrm{IC}_{50}\right]$ value:}

$\mathrm{IC}_{50}$ value is nothing but the concentration required to kill $50 \%$ of the cell population [44]. The cytotoxicity of both the fungicides was expressed in terms of $\mathrm{IC}_{50}$ value, using linear regression equation. The $\mathrm{IC}_{50}$ value of carbendazim was 73.20 $\mu \mathrm{g} / \mathrm{ml}$ for $\mathrm{HaCaT}$ cells and $62.01 \mu \mathrm{g} / \mathrm{ml}$ for HepG2 cells. The results indicated that the carbendazim was more cytotoxic to hepatoma cells than the keratinocytes. The results supported the work carried on HepG2 and NIH 3T3 cells on propiconazole fungicide exposure, showing $\mathrm{IC}_{50}$ value $41.025 \mu \mathrm{g} / \mathrm{ml}$ [43]. Further on treatment with copper oxychloride the $\mathrm{IC}_{50}$ value for HaCaT cells was $67.36 \mu \mathrm{g} / \mathrm{ml}$ and $75.12 \mu \mathrm{g} / \mathrm{ml}$ for HepG2 cells, indicating the copper oxychloride was more harmful to skin than the liver [table 1].

Table 1: Effect of carbendazim and copper oxychloride on HaCaT and HepG2 cells at different concentrations.

\begin{tabular}{|c|c|c|c|c|}
\hline sample & Cell line & $\begin{array}{c}\text { Concentration } \\
\mu \mathrm{g} / \mathrm{ml}\end{array}$ & $\begin{array}{c}\text { Percentage } \\
\text { of cell } \\
\text { viability }\end{array}$ & $\begin{array}{c}\mathrm{IC}_{50} \\
\text { value } \\
\mu \mathrm{g} / \mathrm{ml}\end{array}$ \\
\hline \multirow{7}{*}{ carbendazim } & \multirow{7}{*}{$\mathrm{HaCaT}$} & control & 100 & \multirow{7}{*}{73.20} \\
\hline & & 20 & $51.48 *$ & \\
\hline & & 50 & $57.19^{*}$ & \\
\hline & & 150 & 41.79 & \\
\hline & & 250 & 36.11 & \\
\hline & & 350 & 37.63 & \\
\hline & & 450 & 35.86 & \\
\hline \multirow{7}{*}{$\begin{array}{c}\text { copper } \\
\text { oxychloride }\end{array}$} & \multirow{7}{*}{$\mathrm{HaCaT}$} & control & 100 & \multirow{7}{*}{67.36} \\
\hline & & 20 & $51.48 *$ & \\
\hline & & 50 & $68.29^{*}$ & \\
\hline & & 150 & 27.85 & \\
\hline & & 250 & 3.37 & \\
\hline & & 350 & -0.094 & \\
\hline & & 450 & -0.37 & \\
\hline \multirow{7}{*}{ carbendazim } & \multirow{7}{*}{ HepG2 } & control & 100 & \multirow{7}{*}{62.01} \\
\hline & & 20 & $58.53^{*}$ & \\
\hline & & 50 & $51.79 *$ & \\
\hline & & 150 & 43.90 & \\
\hline & & 250 & 40.67 & \\
\hline & & 350 & 37.94 & \\
\hline & & 450 & 30.98 & \\
\hline \multirow{7}{*}{$\begin{array}{c}\text { copper } \\
\text { oxychloride }\end{array}$} & \multirow{7}{*}{ HepG2 } & control & 100 & \multirow{7}{*}{75.12} \\
\hline & & 20 & $58.53 *$ & \\
\hline & & 50 & $68.14 *$ & \\
\hline & & 150 & 23.09 & \\
\hline & & 250 & 19.15 & \\
\hline & & 350 & 5.59 & \\
\hline & & 450 & 0.21 & \\
\hline
\end{tabular}

[*] indicates the values nearing to the $\mathrm{IC}_{50}$ value

\section{CONCLUSION}

In conclusion, the results show that these fungicides have deleterious effects on human health. The in vitro study on the short 
term exposure of Hacat and HepG2 cells to different concentrations of carbendazim and copper oxychloride revealed that the constant exposure to these fungicides can be harmful to human skin as well as well as on the liver.

Furthermore the long term exposure to both fungicides may lead to adverse effects on environment, soil, and other living beings. Therefore more research is needed, to understand the detoxification of these fungicides. The study suggests that, more care should be taken while handling these pesticides.

\section{ACKNOWLEDGEMENT}

Financial support and sponsorship: The authors are thankful to the Department of Biotechnology [DBT], Ministry of Science and Technology, Government of India, New Delhi, for funding the Bioinformatis infrastructure facility project [BT/BI/25/001/2006 VOL II date 05-03-2012], the interdisciplinary programme for life science project [BT/PR/4555/INF/22/126/2010 dated 30-9-2010], UGC-UPE fellowship and the P. G. Department of Biotechnology and Microbiology, Karnatak University Dharwad, for providing the necessary facilities.

Conflict of Interests: There are no conflicts of interest.

\section{REFERENCE}

1. Gupta PK. Toxicology of pesticides: a review of the problem. In Proc Sem Eff Pest Aq Fau (Agarwal VS, Rana SV, eds.). Jagmander Book Agency, New Delhi, India, pp. 1984;19-36

2. Gupta PK. Pesticides. In: Gupta, P.K., Salunkhe, D.K.(Eds.), Modern Toxicology. Metropolitan Book Company, New Delhi, pp. 1985;160.

3. Shetti AA, Kaliwal BB. Biodegradation of imidacloprid by soil isolates Brevundimonas sp. MJ15. I. J.Curr. Res., 2012;4(10): 100106.

4. Gupta PK. Pesticides in the India environment. Interprint, New Delhi, pp. 1986;1-206.

5. Kovach J, Petzoldt C, Degni J, Tette J. A method to measure the environmental impact of pesticides. New York's Food and Life Sciences Bulletin No. 139: IPM Program, Cornell University, New York Agricultural Experiment Station. 1992

6. Gupta PK. Veterinary Toxicology. Cosmo Publications, New Delhi, India. 1988

7. Singhal LK, Bagga S, Kumar R, Chauhan RS. Down regulation of humoral immunity in chickens due to carbendazim. Toxicol In-vitro 2003;17:687-92.

8. Alt ER, Sternlieb I, Goldfischer S. The cytopathology of metal overload. Int Rev Exp Pathol 1990;31:165-188

9. Goldstein S, Czapski G. The role and mechanism of metal ions and their complexes in enhancing damage in biological systems or in protecting these systems from the toxicity of O2. J 2 Free Radic Biol Med 1986;2:3-11

10. Noakes DN. and Sanderson DM. A method for determining the dermal toxicity of pesticides. Br. J. Ind. Med. 1969;26: 59-64

11. Westerink WM, Schoonen WG. 2007. Cytochrome P450 enzyme levels in HepG2 cells and cryopreserved primary human hepatocytes and their induction in HepG2 cells. Toxicol In Vitro. 21 2007; 15811591.

12. Knasmu" ller S, Mersch-Sundermann V, Kevekordes S, Darroudi F, Huber WW, Hoelzl C, Bichler J, Majer BJ, Use of human-derived liver cell lines for the detection of environmental and dietary genotoxicants; current state of knowledge. Toxicology 2004; 198:315-328.

13. Bondesson I, Ekwall B, Hellberg S, Romert L, Stenberg K, Walum E. MEIC-A new international multicenter project to evaluate the relevance to human toxicity of in vitro cytotoxicity tests. Cell Biol Toxicol. 1989;5:331-347.

14. Devidse LC. Antimitotic activity of methyl benzimidazol-2-ylcarbendazimamate in Aspergillus nidulans. J.cell boil. 1973;72. 174.

15. Berridge MV, Herst PM, Tan AS. Tetrazolium dyes as tools in cell biology: new insights into their cellular reduction. Biotechnology Annual Review, 2005;11: 127-152.

16. Wang HZ, Chang CH, Lin CP, Tsai MC () Using MTT viability assay to test the cytotoxicity of antibiotics and steroid to cultured porcine corneal endothelial cells. J Ocul Pharmacol Ther 1996;12:35-43.

17. Chang HS, Bae SM, Kim YW, et al. Comparison of diarsenic oxide and tetraarsenic oxide on anticancer effects: relation to the apoptosis molecular pathway. Int J Oncol 2007;30:1129-35

18. Walker GM. Cell cycle specificity of certain antimicrotubular drugs in Schizosaccharomyces pombe. J Gen Microbiol 1982;128:61-71.

19. Tomlin CDS. The Pesticide Manual. British Crop ProtectionCouncil, Farnham, UK. 1997

20. Barnes TB, Verlangieri AJ, Wilson MC. Reproductive toxicity ofmethyl-1-(butylcarbendazimamoyl)-2-benzimidazole carbendazimamate (benomyl) inmale Wistar rats. Toxicology 1983;28:103-15.(10)

21. Hess RA, Moore BJ, Forrer J, Linder RE, Abuelatta AA. The fungicidebenomyl (methyl 1-(butylcarbendazimamoyl)-2benzimidazolecarbendazimamate) causes tes-ticular dysfunction by inducing the sloughing of germ-cells and occlusion ofefferent ductules. Fundam Appl Toxicol 1991;17:733-45.

22. Graham CH, Hawley TS, Hawley RG, Macdougall JR, Kerbel RS, Khoo N, et al. Establishment and characterization of 1st trimester human trophoblast cells with extended life-span. Exp Cell Res 1993;206:204-11.

23. Yenjerla M, Cox C, Wilson L, Jordan MA. Carbendazim inhibits cancer cell proliferation by suppressing microtubule dynamics. J Pharmacol Exp Ther 2009;328:390-8.

24. Satake M, Mido YH, Yasuhisa S, Taguchi MS Sethi ,SA Igbal. Environmental Toxicology. Discovery Plublishing House., New Delhi, pp: 1997;153-197.

25. Marchal Sequalt D. The effect of commercial preparations of Benlate, Dithane M45, Copper sulfate and Dichlofluanid on the fertility of Drosophila melanogaster Meigen. J Environ Sci Health 1993 ;B 28(4): 397-411

26. Marchal Sequalt D, Lauge G . Ovarian activity of Drosophila melanogaster Meigen (Diptera) during a chronic intoxication with four fungicides: anatomical and cytological study. J Environ Sci Health 1997;B 32(3): 411-428.

27. JC.Wataha, Biocompatibility of dental casting alloys: a review, J. Prosthet. Dent. 83 2000; 224-234.

28. N.S. Aston, N.Watt, I.E. Morton, M.S. Tanner, G.S. Evans, Copper toxicity affects proliferation and viability of human hepatoma cells, Hum. Exp. Toxicol. 19 2000; 367-376. 
29. M.C. Cortizo, M. Fernández Lorenzo de Mele,A.M. Cortizo,Metallic dental material biocompatibility in osteoblastlike cells: correlation with metal ion release, Biol. Trace Elem. Res. 100 2004; 151-168.

30. J Yang, Q Li, H Yang, L Yang, L Yu. Overexpression of human CUTA isoform2 enhances the cytotoxicity of copper to HeLa cells, Acta Biochim. Pol. 55 2008; 411-415.

31. M Hayashi, S Fuse, D Endoh, N Horiguchi, K Nakayama, Y Kon, T Okui. Accumulation of copper induces DNA strand breaks in brain cells of Long-Evans Cinnamon rats, an animal model for human Wilson disease, Exp. Anim. 55 2006; 419-426.

32. BL Preston, J Shackelford. Risk-based analysis of environmental monitoring data: application to heavy metals in North Carolina surface waters, Environ. Manage. 30 2002; 279-293.

33. XE Yang, XX Long WZ, Ni, ZQ Ye, ZL He, PJ Stoffella, DV, Calvert, Assessing copper theresholds for phytotoxicity and potential dietary toxicity in selected vegetable crops, J. Environ. Sci. Health Bull. 37 2002; 625-635.

34. T Knakievicz, HB Ferreira, Evaluation of copper effects upon Girardia tigrina freshwater planarians based on a set of biomarkers, Chemosphere 2007.

35. D Wang, $\mathrm{X}$ Du, $\mathrm{W}$ Zheng, Alteration of saliva and serum concentrations of manganese, copper, zinc, cadmium and lead among career welders, Toxicol. Lett. 176 2008; 40-47.

36. PG Georgopoulos, A Roy, MJ Yonone-Lioy, RE Opiekum, PJ Lioy. Environmental copper: its dynamics and human exposure issues, J. Toxicol. Environ. Health B. Crit. Rev. 4 2001; 341-394.

37. MS. Tanner, Role of copper in Indian childhood cirrhosis, Am. J. Clin. Nutr. 67 1998; 1074-1081.

38. T Muller, H Feitchtinger, H Berger, W Muller, Endemic tyrolean infantile cirrhosis: an ecogenetic disorder, Lancet 347 1996; 877880.

39. T Wu, CT Sempos, JL Freudenheim, P Muti, E Smit., Serum iron, copper and zinc concentrations and risk of cancer mortality in US adults, Ann. Epidemiol. 14 2004;195-201.
40. N Leone, D Courbon, P Ducimetiere, M Zureik, Zinc, copper and magnesium and risks for all-cause cancer and cardiovascular mortality, Epidemiology 17 2006; 308-314.

41. M Di Donato, B Sarkar, Copper transport and its alterations in Menkes and Wilson diseases, Biochim. Biophys. Acta 1360 1997; $3-$ 16.

42. GJ Brewer, Zinc acetate for the tratment of Wilsons disease, Expert Opin. Pharmacother. 2 2001; 1473-1477.

43. Satapute PP, Kaliwal BB, In vitro Toxicity screening of triazole fungicide propiconazole,

44. International Journal of Recent Scientific Research, vol.6, 2015; 6525-6528

45. Badisa RB, Darling -Reed SF, Joseph P, Cooperwood LM, Latinwo, Goodman CB. Selective cytotoxic activities of two novel synthetic drugs on human breast carcinoma MCF-7 cells. Anticancer Res. 29 2009; 293-2996.

\section{How to cite this article:}

Bakre DS, Kaliwal BB. In-vitro Assessment of Carbendazim and Copper oxychloride cytotoxicity on $\mathrm{HaCaT}$ and $\mathrm{HepG} 2$ human cell lines. J App Biol Biotech. 2017; 5 (03): 023-029. 